\title{
ICONOGRAFÍA DEL PODER: PROBABLE DIBUJO DE CHURRIGUERA PARA LA ENTRADA EN MADRID DE FELIPE V (1701)
}

\author{
POR \\ TERESA ZAPATA FERNÁNDEZ DE LA HOZ \\ Doctora por la Universidad Autónoma de Madrid
}

\begin{abstract}
National Library in Madrid has recently acquired a magnificent drawing corresponding to an ephimeral decoration, which was virtually unedited, since its location has been unknown from 1926 when the Antique Madrid Exhibition was held, until its recent appearance in Feriarte. In the present paper the formal, stilistic, and specially iconographic aspects of this important drawing are analyzed, which lead the author to consider it as a project for one of the ephimeral architectures built for the celebration of Philip V royal entry to the Court on 1701, probably of José de Churriguera.
\end{abstract}

La Biblioteca Nacional de Madrid acaba de adquirir un magnífico dibujo, representativo del más sugestivo barroco efimero ${ }^{1}$ (Fig. 1). Expuesto en la pasada edición de Feriarte, celebrada en Madrid en noviembre de $1994^{2}$, perteneció a la colección de don Félix Boix, figurando en la Exposición del Antiguo Madrid, organizada por la Sociedad Española de Amigos del Arte, en 1926, como de José de Churriguera ${ }^{3}$. Hasta su aparición en Feriarte se desconocía su paradero, lo que viene a aumentar su interés.

El dibujo reproduce un tramo de arquitectura, a modo de portada, formada por un hueco o paso central terminado en arco de medio punto, almohadillado ligado con labores de incrustaciones alternando rosetas con ranuras pareadas, y cuatro tramos laterales arquitrabados, dos a cada lado. El central está flanqueado por pilastras, adornadas con cartelas de las que penden racimos de frutas, que sostienen la cornisa que remata el frontón triangular situado sobre el arco de medio punto, decorado con una cartela. Sobre la cornisa descansan dos grandes volutas que sirven de base a otra cartela ovalada, rematada por una corona real y sostenida por dos niños de cuerpo entero. Los tramos laterales, levantados sobre un zócalo decorado asimismo con cartelas,

\footnotetext{
1 Mide $435 \times 850 \mathrm{~mm}$. y está realizado a lápiz, pluma y aguadas sepia y azulada sobre papel blanco verjurado. Está bastante deteriorado, con pérdidas de papel en los ángulos superior e inferior derecho. Es imposible ver si tiene filigrana, por estar pegado a un segundo soporte.

2 Se expuso en el stand de don Vicente Coll, Antigüedades, de Barcelona, a quien agradezco las facilidades que me ha dado para su estudio.

3 Núm. 358 del catálogo-guía, como Decoración para la plazuela de la Villa, en la entrada de María Luisa de Orleans.
} 


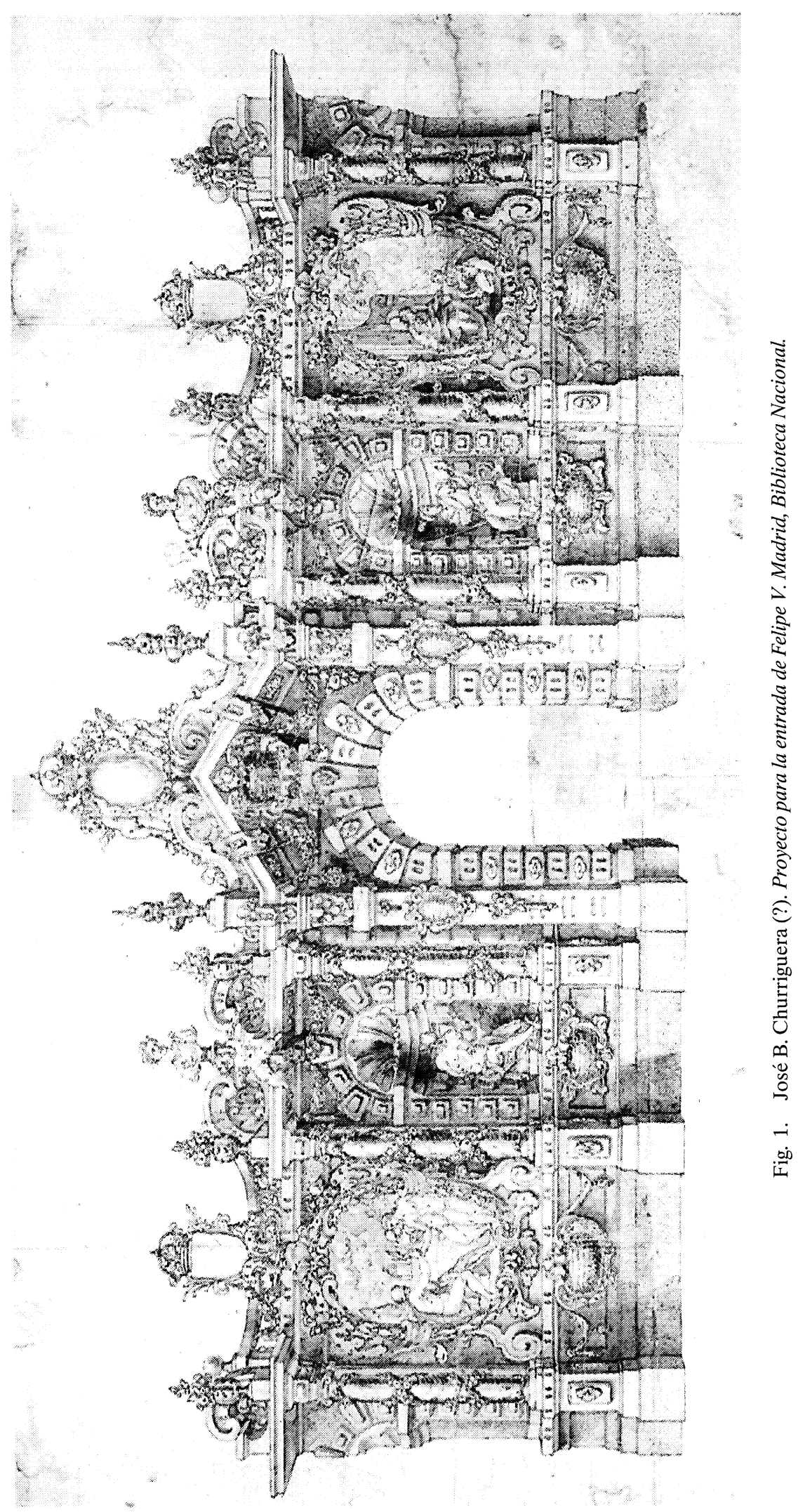


están delimitados por columnas jónicas apoyadas sobre pilares, con sus fustes ceñidos con guirnaldas cruzadas de flores y frutos, y coronadas por trozos de entablamento que sostienen la cornisa en voladizo. El interior de los dos más próximos al hueco central está ocupado por un nicho almohadillado con incrustaciones, que cobija una estatua sedente; un busto de emperador romano sobre un pedestal sostenido por un niño y flanqueado por dos volutas aveneradas tipo orejeras, decoradas con ranuras, forman su coronamiento. Los otros dos, de tamaño mayor y retranqueados, están ocupados por una gran cartela ovalada profusamente decorada, apoyada sobre dos volutas, que sirve de marco a un lienzo en el que se representa una historia; un tramo de balaustrada semicircular, terminada en una bola y decorada con una escudo de armas en su parte central, forman el coronamiento de cada uno de estos dos tramos. Guirnaldas de flores y frutos, hojas de acanto, espigas, cintas, niños, jarrones con flores, flameros, incrustaciones, ranuras pareadas, etcétera, completan la exhuberante ornamentación de esta decoración efimera, a la que habría que añadir el colorido de los mármoles y jaspes de diferentes colores que, como era habitual, se imitaban en su arquitectura; el dorado o plateado de las estatuas, así como de la mayoría de los adornos; las diferentes tonalidades de sus lienzos, destinado a ocultar la pobreza de los materiales con los que se fabricaban -madera, lienzo, pasta de papel, yeso, etcétera-, que el autor del dibujo ha tratado de sugerir mediante la utilización de las aguadas sepia y azulada.

Pero si importante era dotar a estas arquitecturas de una apariencia externa lujosa, suntuosa, espectacular, sorprendente, como la que nos transmite este dibujo, que nos puede recordar los modelos fantásticos de Wendel Dietterlin ${ }^{4}$, no lo era menos su contenido interno, su simbolismo, su mensaje ideológico, expresado, fundamentalmente (no hay que olvidar el simbolismo de la propia arquitectura), a través de las «historias» representadas en sus cuadros y los personajes o alegorías materializados en sus esculturas; dos componentes -lo puramente visual y lo simbólico- con los que el arte efimero va a expresar, mejor que cualquier otra manifestación artística, los principios del poder absoluto.

Como acabo de indicar, los cuatro tramos laterales de esta arquitectura se adornaban con dos pinturas y dos esculturas. Comenzando por los dos lienzos, el de la izquierda (Fig. 2) representa un personaje masculino, prácticamente desnudo, sentado a la izquierda, delante de un monte, con un gorro o turbante que le cubre la cabeza y un manto por la espalda que se dobla sobre su brazo izquierdo, en cuya mano sostiene un cayado que descansa sobre sus piernas. El brazo derecho está extendido y en actitud de depositar algo sobre la mano derecha del personaje femenino que, desnudo y de pie, está situado enfrente de él. Este personaje luce como único atavio una corona de flores alrededor de la cabeza y está acompañado de un niño abrazado a su pierna, del que únicamente se aprecia un brazo y parte del rostro. Detrás, en segundo plano, aparece un tercer personaje, también desnudo, que cubre su cabeza con un casco. Su brazo derecho sostiene un manto, mientras que la mano está señalando al cielo. Al fondo se divisa una puerta de muralla y un tramo de lienzo internándose en la lejanía.

La historia representada no es otra que el célebre Juicio de París, con el que se inicia el ciclo de Troya ${ }^{5}$. Hermes, el mensajero de los dioses, acompañado de Hera, Atenea y Afrodita, acude en busca de Paris al monte Ida, donde se encontraba cuidando de su ganado, para que, siguiendo las órdenes de Zeus, entregara la manzana de oro de la Discordia a la diosa que juzgara más bella. Zeus lo había elegido como árbitro en la disputa entre las tres diosas por haberle agradado con anterioridad el comportamiento del joven, al no haber dudado en coronar a Ares, quien transfor-

\footnotetext{
${ }^{4}$ La obra de W. DietTerlin, Architectura, Estrasborgo, 1594 (de la que existe edición facsimil, New York, 1968), formaba parte de algunas de las bibliotecas de artistas y eruditos del siglo xvil.

5 Sobre este episodio en particular y sobre la historia de Troya en general, véase Antonio RuIz DE ElvirA, Mitología clásica, Madrid, 1975, págs. 387-443.
} 
mado en toro había logrado vencer al mejor ejemplar de su rebaño. Las tres diosas posan ante él e intentan sobornarlo con diferentes recompensas a cambio de ser elegidas. Atenea le ofrece la sabiduría y la victoria; Hera, convertirle en soberano de Asia y en el hombre más rico del mundo, y Afrodita, el amor de la mujer más hermosa, personificada en Helena de Esparta. Esto es lo que más agradó a París, por lo que entregó la manzana a la diosa del amor.

Esta última parte del episodio es la que se representa en el dibujo. París, con el gorro de pastor y el cayado, está entregando a Afrodita, acompañada de su hijo Cupido, la manzana que le acaba de entregar Hermes, tocado con su característico petaso o casco alado, quien le está indicando con su mano que sigue instrucciones de Zeus. Al fondo, la amurallada Ilión.

El Juicio de París se cita en la Iliada (L XXIV, 25-30), aunque sin mencionar el incidente de la Discordia en las bodas de Tetis y Peleo ni, por supuesto, la manzana. Entre los autores posteriores que se refieren a este episodio están Apolodoro, en su Biblioteca, Ovidio, en Heroidas, Higino en su Mithologia y Apuleyo en su Metamorfosis o Asno de Oro ${ }^{6}$. De todos ellos, el que proporciona un relato más completo y descriptivo $\mathrm{y}$, por tanto, de mayor interés desde el punto de vista iconográfico, es Apuleyo, quien en su Metamorfosis (L X, cap. VI) describe la representación que del Juicio de París hicieron unos actores ambulantes. Apuleyo se refiere al monte Ida, reproducido en madera por los comediantes; describe al pastor Paris vestido con un sombrero de oro en la cabeza y una túnica al hombro; a Mercurio (Hermes), desnudo, con un manto blanco sobre el hombro izquierdo, entregándole a Paris una manzana de oro a la vez que le indicaba por señas las órdenes de Júpiter (Zeus). Cómo, de las tres diosas, Venus (Afrodita) iba desnuda, excepto un sutil velo de seda, y acompañada de Cupido, cómo le ofrecieron sus dones y cómo, finalmente, Paris puso la manzana en la mano de Venus en señal de victoria. Del Asno de Oro se publicaron numerosas ediciones en lengua castellana durante el siglo XVI y XVII ${ }^{7}$. Por otro lado, Baltasar de Vitoria, en su Theatro de los Dioses de la Gentilidad (1620-1623), obra muy utilizada durante el siglo XviI por iconógrafos y artistas, incluye la historia de París y el célebre juicio ${ }^{8}$.

Este episodio fue muy representado en pintura, tanto en el Renacimiento como en el Barroco: Rafael, Giulio Romano, Luca Cambiaso, Pelegrino Tibaldi, Anibal Carracci, Albano, Rubens, Teniers, Jordaens, Lanfranco, Maratti, Luca Giordano y otros ${ }^{9}$. En España, aunque no muy frecuente, si se conocen algunos ejemplos, recogidos por la profesora Rosa López Torrijos en su Mitología del Siglo de Oro, como el Juicio de Paris pintado por Juan de Juanes, del Museo de Udine (Italia) ${ }^{10}$; el pintado por Juan de la Corte, ya en el siglo xvII, para la finca El Retiro de Torremolinos, dentro de un ciclo dedicado a Troya ${ }^{11}$. Otro cuadro de este tema, también de Juan de la Corte, se cita en un inventario de pinturas del Buen Retiro, formando asimismo parte de otra serie sobre Troya ${ }^{12}$. Igualmente, en el inventario de los bienes de Claudio Coello, realizado a su muerte, se incluye un Juicio de Paris considerado de su mano ${ }^{13}$. Dentro de la literatura emblemática, tan consultada por cuantos colaboraban en el proyecto decorativo festivo, encon-

6 Ibid., págs. 395 y ss.

7 Consultada la edición castellana de Madrid, 1601, traducida por Juan Vázquez de Mármol.

8 I Parte del Theatro de los dioses de la Gentilidad, Salamanca, MDCXX, Libro II, cap. XX, pág. 144.

9 A. PIgler, Barockthemen. Eine Auswahl von verzeichnissen zur Ikonographie des 17. und 18. Jahrhunderts, Budapest, 1974, págs. 204-212.

10 A. E. Pérez Sánchez, "Juan de Juanes en su centenario», Archivo de Arte Valenciano, 1979, pág. 13; LóPez TorriJos, La Mitología en la pintura española del Siglo de Oro, Madrid, 1985, pág. 196.

11 D. Angulo Iñiguez y A. E. Pérez Sanchez Pintura madrileña. Primer tercio del siglo xvil, C.S.I.C., Madrid, 1969, pág. 360; R. LóPEz TORRIJOS, ob. cit., pág. 206.

12 Ibid.

13 Saltillo, "Artistas madrileños (1592-1850)", B.S.E.E., 1953, pág. 198 y R. López TorriJos, ob. cit., pág. 216. E. J. Sullivan en su obra Claudio Coello, Madrid, 1989, donde transcribe el documento (págs. 311-315), considera que no se puede asegurar que todas las pinturas que figuran en el inventario de los bienes del artista fueran de su mano. 
tramos un Juicio de Paris en los Emblemas moralizadas, de Hernando de Soto (1599). El emblema lleva por título "Todo lo vence el amor» y en el grabado que lo ilustra, algo torpe, se representa a Paris ofreciendo a Venus la manzana bajo la mirada de las otras dos diosas ${ }^{14}$. La historia, que interesó a muchos de nuestros literatos del siglo xvi, sirvió también de tema a una comedia de autor desconocido, titulada EI Juicio de Paris, representada en el Coliseo del Buen Retiro, el 8 de noviembre de 1686, para celebrar el cumpleaños de Carlos II ${ }^{15}$. En fecha posterior, Palomino representó esta historia en uno de los dos calesines que se construyeron para Carlos II, en 1696, cuya decoración fue ideada y ejecutada por el artista, Pintor del Rey en esas fechas ${ }^{16}$. La idea principal del segundo calesín fue, según nos cuenta el propio autor, «ponderar los triunfos de la Belleza y el imperio del Amor;» ${ }^{17}$, por eso, en la parte posterior representó a Venus en su carro tirado por dos palomas, acompañada de Cupido, triunfante sobre Júpiter, Juno, Neptuno y Plutón. La historia del Juicio de Paris la dividió en tres escenas: en el costado derecho, Júpiter entregando a Mercurio la manzana de oro con el encargo de que se la lleve a $\mathrm{Pa}$ rís, en el monte Ida, para que después de juzgar a la tres diosas se la entregue a la más perfecta; en el costado izquierdo, la diosa Venus, acompañada de Cupido, caminando por un campo que se iba cubriendo de flores a su paso; en la parte delantera, París entregando la manzana de oro a Venus, mientras Juno y Minerva estaban vistiéndose, ésta última "despechada con airoso ademán encajándose la celada, como ofendida del desprecio.» ${ }^{18}$.

De todos estos ejemplos, la fuente iconográfica que más se aproxima al dibujo es el tema central del grabado de Marcantonio Raimondi sobre dibujo de Ralael ${ }^{19}$ (Fig. 3), con algunas variaciones. La principal es la supresión de las otras dos diosas, siempre presentes en los otros cuadros sobre este tema, debido, tal vez, al formato alargado de la cartela o por haber querido centrar el episodio en el instante final: la elección de Venus. Otra diferencia apreciable es la situación de Mercurio, que aparece en el dibujo acompañando a la diosa y no detrás de Paris, como en el grabado o en la mayoría de los cuadros que sobre este tema se conocen. Sin embargo, en el grabado también su brazo derecho se dirige hacia el lugar en el que se representa a Júpiter sentado en su trono (ángulo superior derecho). Donde sí encontramos a Mercurio acompañando a Venus en su misión de mensajero de Júpiter es en el primero de la serie de frescos sobre la guerra de Troya que decoran la Sala de Troya del Palacio Ducal de Mantua, diseñados por Giulio Romano y realizados por sus discípulos ${ }^{20}$ (Fig. 4). Estos cambios, así como la representación del monte situado detrás de Paris, y de la ciudad amurallada del fondo, aparte de deberse, con toda probabilidad, a un deseo del artista de realizar una composición más personal, nos indica también la importancia que los textos literarios manejados por el erudito del turno, por el propio artista, tenían en esta clase de decoraciones. Lo que no deja de sorprender es la desnudez de los tres personajes, en particular la de Venus, nada frecuente en la pintura española del siglo xviI, cuando incluso en el texto de Apuleyo o en el grabado de Marcantonio la diosa se cubre con un cendal. Sí aparece completamente desnuda en el grabado del emblema de Hernando de Soto y en el cuadro de Jordaens de la National Gallery de Washington ${ }^{21}$ (Fig. 10). Esta iconografía nos puede indicar que esta decoración estaba destinada al recibimiento de un perso-

\footnotetext{
14 Fol. 36 v. Existe edicición facsímil de la Fundación Universitaria Española, Madrid, 1983.

15 N. D. Shergold y J. E. VArey, Representaciones palaciegas: 1603-1699. Estudio y Documentos, Tamesis Book Limited, London, 1982, pág. 252.

16 A. Palomino, El Museo Pictórico y Escala Optica, Madrid, 1715-1724, págs. 670-674, edición de Aguilar, 1947.

7 Ibid., pág. 672.

18 Ibid., pág. 673.

9 Bartsch, T 26, The works of Marcantonio Raimondi and his school, New York, 1978, 245-I (197), pág. 242.

20 Frederick Hartt, Giulio Romano, New Haven, 1958, vol. II, ilust. 401.

21 L. v. Puyvelde, Jordaens, Bruxelles, 1953, pág. 199.
} 

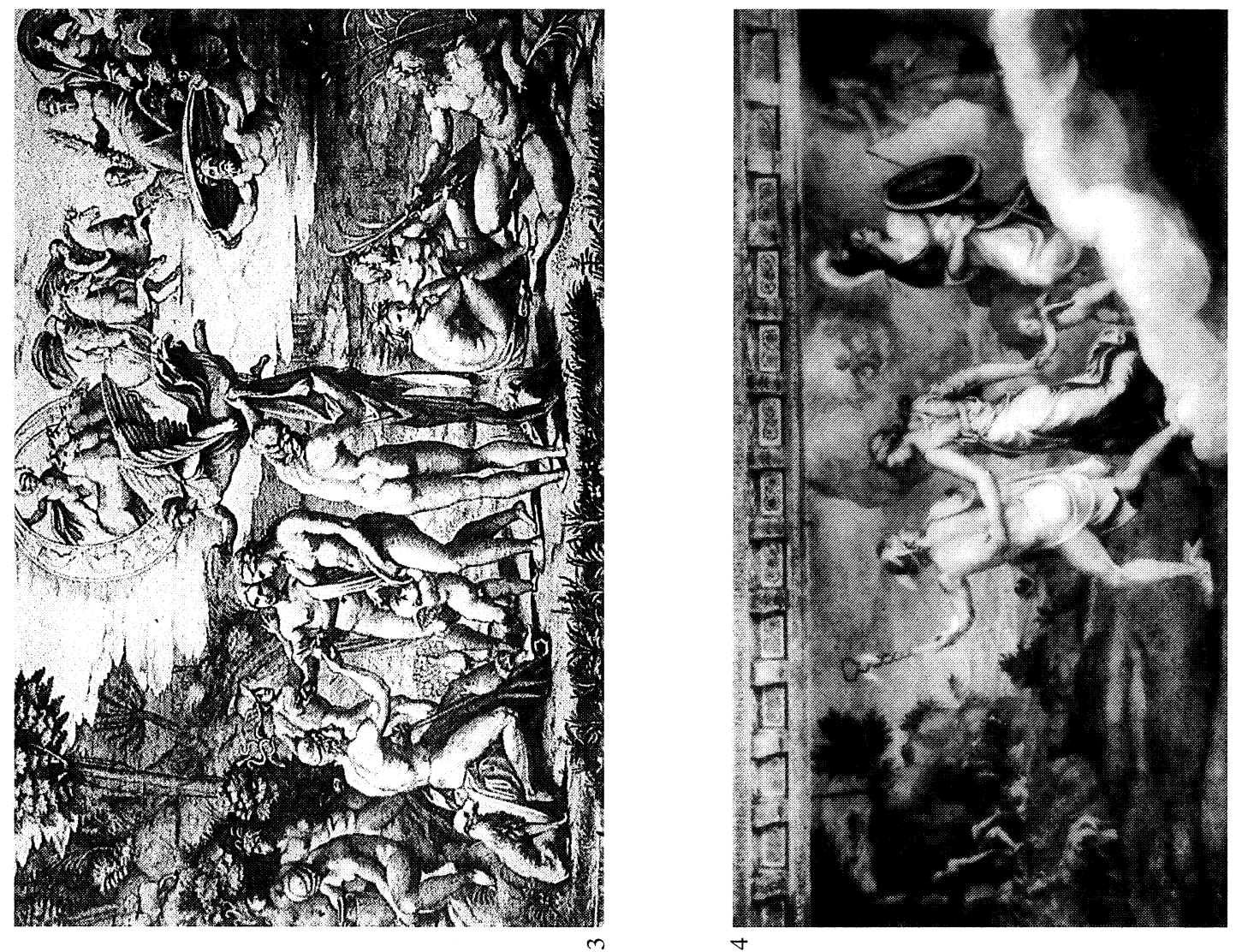

N

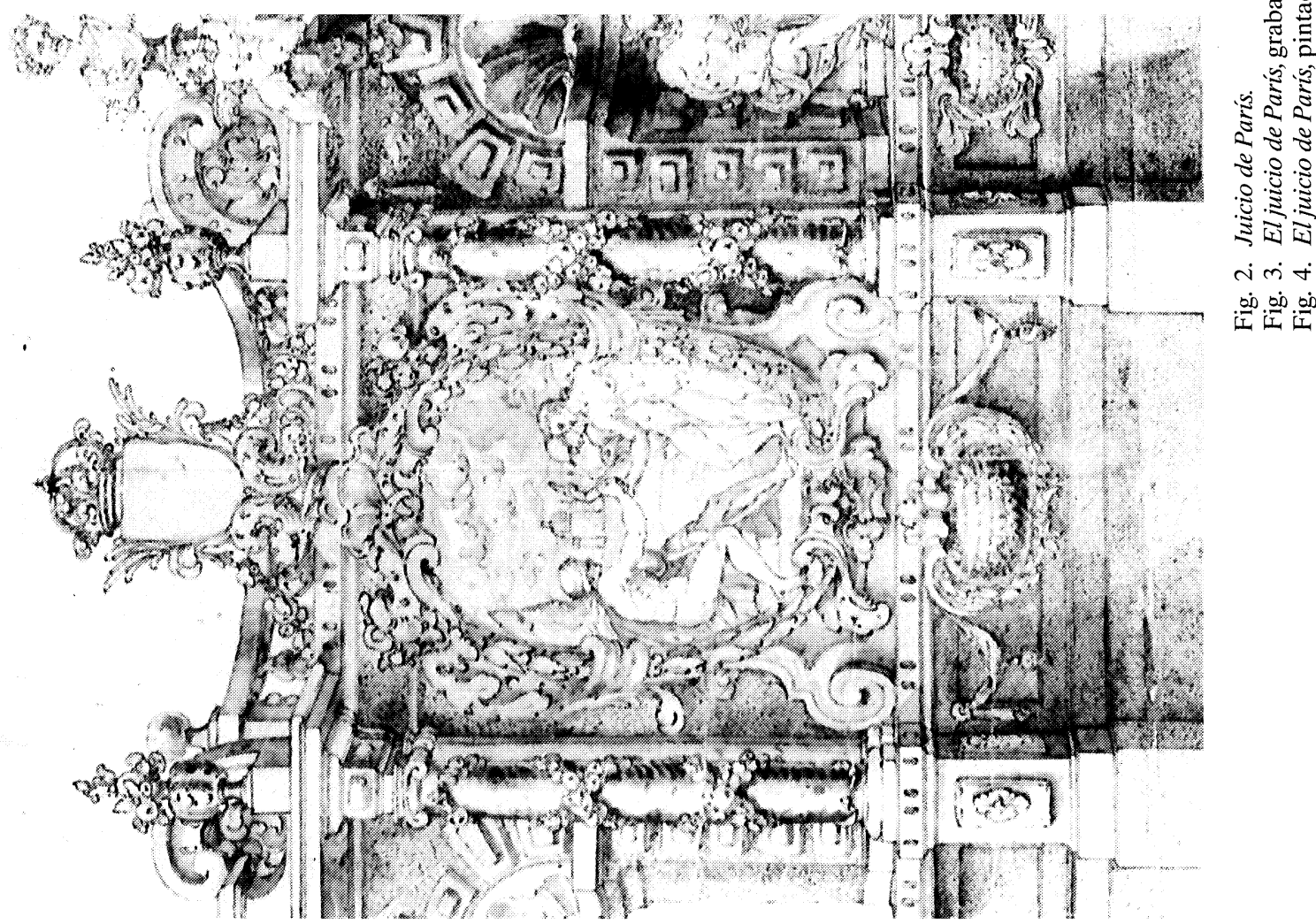


naje masculino, pues, si nos atenemos a la opinión de los teóricos de la pintura durante el siglo xVII sobre el tema del desnudo, resulta impensable en el caso de una entrada destinada a una reina ${ }^{22}$.

El Juicio de Paris es el episodio desencadenante de la guerra de Troya y como tal era el tema con el que comenzaban los ciclos de pintura sobre Troya. Paris solo podía conseguir el amor de Helena arrebatándosela a su esposo Menelao, rey de Esparta, lo que consiguió con la ayuda de Venus. Esto provocó la venganza de los demás reyes griegos, antiguos pretendientes a la mano de Helena, los cuales habían jurado defender al que resultara elegido, es decir, a Menelao. De esta forma dio comienzo la guerra de Troya, que llevara a la destrucción y ruina de la ciudad. En un sentido más amplio, se puede interpretar como presagio de acontecimientos funestos. En cuanto a la interpretación moralizante o didáctica de la historia, Natalis Comitis, en su Mythologiae (1568), lo considera el triunfo de la concupiscencia, de la carne, sobre la sabiduría y la riqueza, dones ofrecidos a Paris por las otras dos diosas, lo que causó la destrucción y la ruina de su patria, por lo que aconseja que se exhorte a los príncipes a que adquieran virtudes dignas de su condición, como la templanza, la continencia y la sabiduría ${ }^{23}$. Para Hernando de Soto (1599) simboliza el triunfo del amor, pero del amor lujurioso que hace perder al hombre los sentidos y la razón ${ }^{24}$. El padre Vitoria (1620) recoge la interpretación de Natalis Comitis en el sentido de que la lascivia sólo trae malas consecuencias ${ }^{25}$. Para Palomino, sin embargo, a finales del siglo XVII, la elección de Venus significa el triunfo de la Belleza y del Amor, como he indicado más arriba.

En el lienzo de la derecha (Fig. 5) se representa a un hombre ataviado con un amplio manto, sentado delante de una arquitectura a modo de trono, que parece atender solícito al personaje que, desnudo aunque con un manto que por la espalda se recoge sobre su brazo, está arrodillado a sus pies en actitud de súplica. A su espalda se aprecia un fondo de agua. En la parte superior, entre nubes, un joven también desnudo, de pie, conduce una cuadriga tirada por al menos tres caballos.

La historia representada es la de Faetón pidiendo a su padre, el dios Sol, que le deje conducir su carro, incluida en las Metamorfosis de Ovidio (L II). Faetón, después de que Epafo, hijo de Júpiter, hubiera puesto en duda que fuera hijo del Sol, pide a su madre, Climene, que le demuestre que es hijo del dios. Climene le dice que acuda él mismo al palacio de su padre y le pida una prueba de que lo es. Así lo hace Faetón y el Sol le jura que le concederá lo que le pida como prueba de su verdadera paternidad. Faetón entonces le pide que le deje conducir por un día la cuadriga en la que el Sol recorre diariamente su órbita celeste. Por la actitud de los dos personajes del dibujo, este momento es exactamente el que se ha querido representar.

La presencia del carro conducido por el joven en la parte superior del dibujo alude a la segunda parte de la historia, cuando, a pesar de que el Sol trata de disuadir a su osado hijo haciéndole comprender lo arriesgado de su petición, éste logra su deseo y cogiendo las riendas del carro emprende la marcha por el espacio celeste. Como de todos es conocido, la aventura termina con la caída de Faetón al río Eridano -sugerido seguramente en el agua que aparece en la parte inferior del dibujo, detrás del joven-, muerto por un rayo lanzado por Júpiter, ante el inminente peligro de que la Tierra perezca abrasada a causa del inexperto conductor.

22 Sobre el problema del desnudo femenino en la pintura española del siglo XvII, véanse los textos de CARDucho, Diálogos de la Pintura (1633); Pacheco, Arte de la Pintura (1649); Garcta Hidalgo, Principios para estudiar el nobilísimo y real Arte de la Pintura (1693), y PALomino, Museo Pictórico y Escala Optica (1724). Este último autor, al referirse a la clase de decoración más adecuada para cada sitio, dice que si se ha de decorar una habitación de señoras «debe huirse totalmente de las fábulas, buscando siempre asuntos nobles, decorosos, honestos, y ejemplares.» (ob. cit., pág. 651).

23 Pág. 1045.

24 Emblemas moralizadas, Madrid, 1599 , fols. 36 v. a 38.

25 Ob. cit., pág. 150. 
La leyenda de Faetón da comienzo al Libro II de las Metamorfosis, considerándose, además, como uno de los relatos más hermosos de esta célebre obra. Ovidio empieza describiendo el palacio del Sol: «El palacio del Sol se elevaba sobre altas columnas y resplandecía de oro reluciente y de piropo que imita a las llamas; tenía los techos cubiertos de brillante marfil, y las dos hojas de la puerta irradiaban con luz de plata.» (1-4). "Cubierto de ropas de púrpura estaba Febo sentado en un trono que resplandecía de brillantes esmeraldas» (24-25) ${ }^{26}$.

La obra de Ovidio, como uno de los textos clásicos más difundidos durante el siglo XVI, es uno de los más utilizados como fuente iconográfica por los autores de programas iconográficos y por los pintores de los siglos XVI y xVII, no faltando en ninguna biblioteca, tanto de eruditos como de artistas. Especialmente interesantes fueron en este sentido las ediciones ilustradas. Entre las traducciones al castellano destacan la de Jorge de Bustamante, en prosa, publicada en Amberes en 1595, de la que se hicieron numerosas ediciones a lo largo de los siglos XVI y xVII, y la de Sánchez de Viana, en verso, publicada también en Amberes en el mismo año. Ambas están ilustradas y las dos incluyen un grabado de Faetón en el palacio del Sol. La iconografía de ambos grabados es muy parecida (Figs. 6 y 7): el dios Sol se representa sentado en el interior de un pórtico elevado sobre varios escalones y sostenido por columnas, ataviado con túnica, manto, corona de laurel y cetro, con el brazo derecho extendido hacia Faetón, quien, cubierto con una túnica, aparece arrodillado a sus pies en actitud de súplica 27.

Este episodio, aunque menos popular que el del Juicio de Paris, cuenta con bastantes ejemplos dentro de la pintura europea de los siglos xvi y xvir: Primaticio, Poussin, Solimena, Pitoni y otros ${ }^{28}$. En España se conocen dos ejemplos del siglo xvi. En primer lugar, se representa en la pieza vecina al Tocador de la Reina, del Palacio de la Alhambra de Granada, decorada con la fábula de Faetón en cuatro escenas, la primera de las cuales corresponde a Faetón pidiendo el carro a su padre, episodio con el que se inicia el ciclo ${ }^{29}$. Asimismo, en el Palacio del Marqués de Santa Cruz, en el Viso, en el centro de una de las salas dedicadas al dios Apolo figura este episodio ${ }^{30}$. En el siglo XVII no se conoce hasta ahora ningún ejemplo de este tema, siendo más frecuente el episodio de la caída del carro ${ }^{31}$. Por el contrario, sí mereció una gran atención por parte de escritores y poetas españoles, tanto del siglo XVI como del XVII ${ }^{32}$, sin olvidarnos del propio Calderón, quien escribió la comedia titulada Faetón, representada el 22 de diciembre de 1679 en el Salón de Comedias del Palacio del Buen Retiro, para celebrar el cumpleaños de la Reina madre, Mariana de Austria, ${ }^{33}$ coincidiendo con la estancia en el palacio de Carlos II y su joven esposa, María Luisa de Orleans, quien desde su llegada a Madrid, el 3 de diciembre, después de su enlace matrimonial, esperaba en el Buen Retiro el día de la entrada oficial en la Corte.

Es bastante probable que de todos estos ejemplos la fuente iconográfica del dibujo fuera la de las Metamorfosis, tanto como fuente literaria elegido por el encargado de seleccionar los temas, como por el artista o artistas encargados de pintarlo, teniendo en cuenta la existencia de ediciones ilustradas en castellano que representaban este episodio. Ahora bien, como en el caso

\footnotetext{
26 Traducción de A. Ruiz de Elvira, Madrid, 1988, págs. 44 y 45.

27 Esta iconografía procede de ediciones más antiguas como la de Venecia, de 1522, o la de Bernardo Salomón, Venecia, 1557.

28 A. Pigler, ob. cit., págs. 217-218

29 D. Angulo, "La mitología en el arte español del Renacimiento», B.R.A.H., 1952, pág. 79.

30 R. López Torrijos, ob. cit., pág. 294.

31 Ibid., pág. 386.

32 Sobre este aspecto, véase A. Gallego Morell, El mito de Faetón en la literatura española, Madrid, 1961.

33 Calderón cobró 3.300 rs. por la composición de la comedia y de la loa; José Caudí, 1.650 rs. por dibujar y fabricar todos los decorados, y Dionisio Mantuano, 2.200 rs. por la dirección y supervisión. (N. D. ShERGOLD y J. E. VAREY, $o b$. cit., págs. 90 y 97). Esta representación era una refundición de una comedia anterior del mismo autor, titulada El Faetonte (J. E. Varey y N. D. Shergold, Comedias en Madrid: 1603-1709, London, 1989, pág. 116).
} 

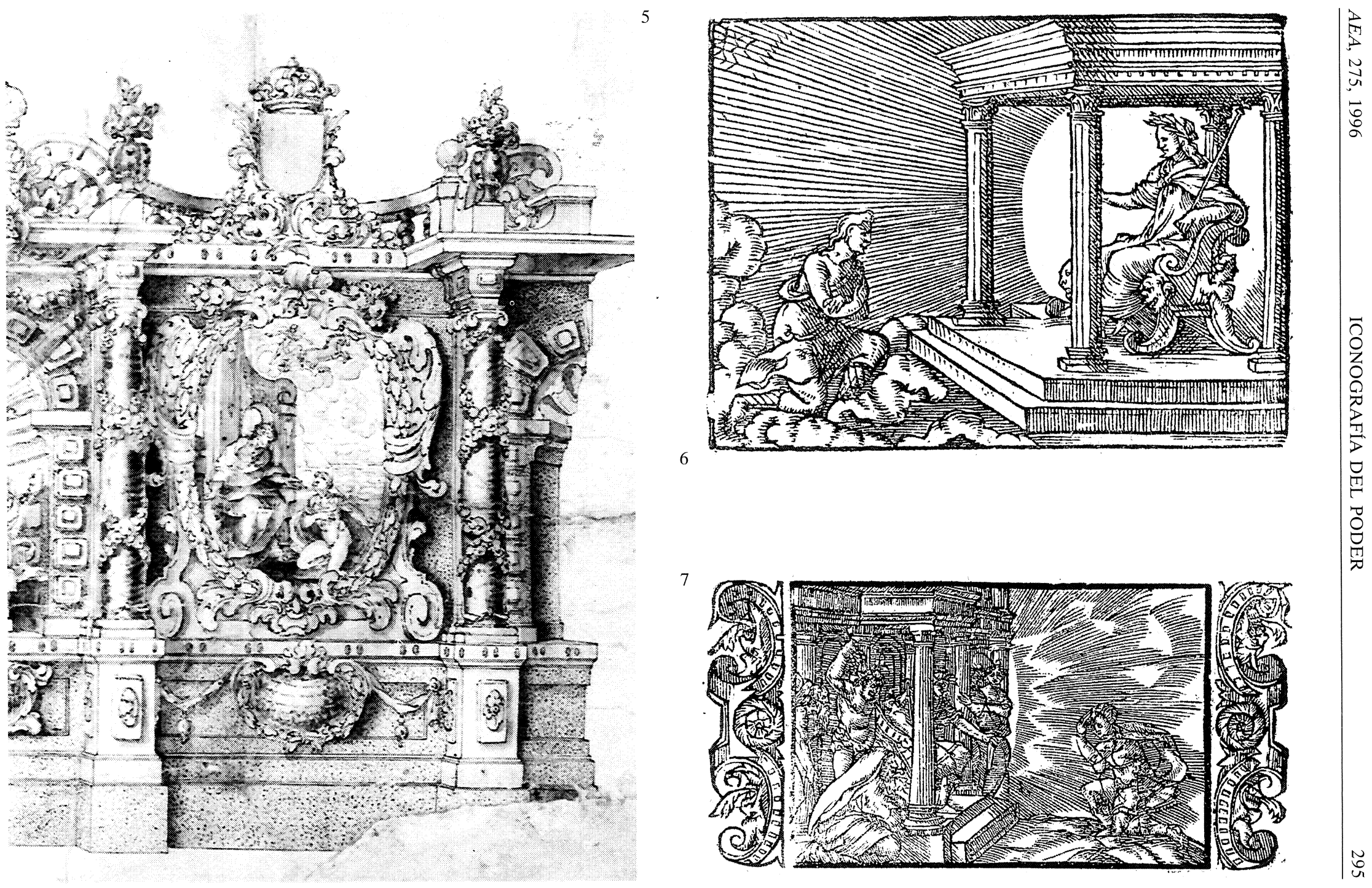

Fig. 5. Faetón pidiendo el carro al dios Sol.

Fig. 6. Faetón pide al dios Sol que le deje conducir su carro, grabado de las Metamotfosis, de Ovidio, edición de J. Bustamante, Amberes, 1595.

Fig. 7. Faetón pide al dios Sol que le deje conducir su carro, grabado de las Metamorfosis, de Ovidio, edición de Sánchez de Viana, Amberes, 1595. 
del Juicio de Paris, la escena se ha simplificado mucho. Así, el palacio del Sol se sugiere únicamente con un muro arquitectónico a modo de telón; los personajes se han reducido a los dos principales, Faetón y su padre, suprimiéndose las personificaciones de las Estaciones, el Día, el Mes y el Año, incluidas en el texto de Ovidio y en la mayor parte de las representaciones del tema (Fig. 8). Si se incluye, en cambio, la segunda parte de la historia, cuando Faetón, una vez obtenido el consentimiento paterno, se sube al carro, con una iconografia muy próxima a la del texto ovidiano: "Ocupa él con su cuerpo juvenil el ligero carro, se yergue sobre él y se goza en tomar en sus manos las ligeras riendas, dando en seguida las gracias a su reacio padre». (L II, 150-55) ${ }^{34}$.

Como en la representación del Juicio de Paris, sorprende también la desnudez del joven Faetón, a quien se suele representar con túnica y manto o, al menos, con un manto que le cubra buena parte del cuerpo. Aunque hay algún ejemplo en el que aparece desnudo, como en el cuadro de Nicolas Poussin, del Museo Dahlen de Berlín ${ }^{35}$, es probable que en el dibujo estuviera impuesto por motivos estéticos, es decir, para armonizar con los desnudos de la otra historia.

Casi todos los autores españoles de los siglos XVI y XVII, dentro de la imperante interpretación moralizante de la mitología, coinciden en considerar a Faetón como el símbolo de la osadía, de la arrogancia, de la soberbia juvenil. Pérez de Moya dice al respecto: "Quisieron los poetas dar a entender por esta fábula que Faetón fue vanaglorioso y arrogante, y presumiendo de sapientísimo sin serlo, sembró entre la simple gente muchas contusiones y falsas doctrinas» ${ }^{36}$. Para el padre Vitoria, Faetón es símbolo de la persona ambiciosa ${ }^{37}$. Especialmente interesantes son las interpretaciones políticas que dos humanistas del siglo XVII dieron a esta fábula. Para Sebastián de Covarrubias, la interpretación moral es que «los gobiernos de reynos, republicas y cosas de gran consideración" no se deben dejar en manos de hombres jóvenes, imprudentes y poco experimentados, «a pena de que ellos perecerán, dexando abrasados y destruydos las provincias" ${ }^{38}$. Diego López, al comentar el Emblea LVI de Alciato "Sobre los temerarios», inspirado en la caída de Faetón, dice: «Entiéndase por Faetón algunos Reyes, Príncipes y Señores, que confiados en sus fuerças y juventud buelven y trastornan de alto a baxo sus cosas y las de sus vasallos, pensando que no ay cosa que no les sea licita, hazedera y fácil. No ay duda sino que si cada uno de los Reyes se contentase con lo que es suyo, vivirían mas quietos y pacíficos y podrían mejor conservar sus tierras y Reyno, que querer usando de las armas tomar mas de lo que pueden, y algunos destos fácilmente los despeña la temeridad como a Faetón» ${ }^{39}$. Por último, en el texto de Calderón de la Barca, que introduce como novedad una rivalidad amorosa entre Epafo y Faetón, el trágico final del hijo del Sol simboliza el castigo a su soberbia ${ }^{40}$. Al lado de estas interpretaciones, que se refieren más bien al momento de la caída del carro, hay otra que se adapta mejor al momento representado en el dibujo, y que seria el deseo de Faetón de ser reconocido por su padre, de legitimar su filiación, lo que, por otra parte, hace el padre, en el momento en que accede a que conduzca el carro.

34 A. Ruiz de ElviRA, ob. cit., pág. 50.

35 A. Blunt, The paintings of Nicolas Poussin. A critical catalogue, London, 1966, pág. 172.

36 I. Pérez de Moya, Philosofia Secreta, Madrid, 1585. Consultada edición de E. Gómez de Baquero, Madrid, 1928 , pág. 192.

37 B. de Vitoria, ob. cit., L V, pág. 550.

38 S. de Covarrubias, Tesoro de la lengua castellana o española, Madrid, 1611. Consultada edición de Barcelona, 1993, pág. 581.

39 D. López, Declaración magistral sobre las Emblemas de Andrés Alciato, Nájera, 1615, pág. 261. Citado por S. SEBASTIÁN en su edición de los Emblemas de Alciato, Madrid, 1985, pág. 91.

40 Sobre esta obra existen copias manuscritas en la Biblioteca Nacional de Madrid con el título de El Faetón, hijo del Sol (Ms. 16399 y 16539). La obra original se publicó en la Cuarta parte de las comedias de Calderón (Madrid, 1672); la representación de 1679 se incluye en la edición de Vera Tassis (Madrid, 1688), con el título de El hijo del Sol, Faetón (Varey y Shergold, ob. cit, pág. 116). 
De las dos estatuas situadas en los nichos, la de la izquierda corresponde a Mercurio representado con sus atributos más característicos, como el pétase, o casco con alas en la cabeza, las alas en los pies y el caduceo o cayado de oro con dos serpientes enrolladas, que aparece apoyado sobre la pared del nicho, a la derecha. Está sentado sobre un pedestal, semidesnudo y con los brazos atados a la espalda con unas gruesas cadenas sujetas a las paredes del nicho, iconografia nada frecuente. Mercurio es el dios inteligente, elocuente y astuto, cuya misión principal es la de mensajero o intérprete de los dioses, en particular de Júpiter, su padre, para el que realizó varias misiones, como la de conducir a las tres diosas ante París, comentada anteriormente. Como inventor de la palabra de los lugares, de la lira y del caramillo, se le considera dios de la elocuencia, de las artes y las letras, y protector de lo caminos y de los comerciantes. La imagen de Mercurio era bien conocida en nuestro país durante el siglo xvir a través de los grabados de la obra de Cartari Imagini de i dei de gli antichi (1556) y de los Emblemas de Alciato (1549), ambos muy difundidos y consultados como fuentes iconográficas. Su presencia es habitual en las entradas reales con esa misión de mensajero de Júpiter, que ha llegado a la Corte acompañando a la nueva reina, quien de esta forma aparece como portadora de los mejores augurios ${ }^{41}$.

La otra estatua representa a la diosa Minerva, la Atenea griega, a quien se suele representar de forma muy parecida a como aparece en el dibujo, es decir, con armadura en el pecho, semicubierta con una clámide anudada al hombro izquierdo, túnica hasta los pies, celada en la cabeza y la lanza y el escudo, que aparecen apoyados contra la pared izquierda del nicho. Como Mercurio, está sentada sobre un pedestal y sus brazos están también atados con unas cadenas sujetas al muro del nicho, iconografia asimismo un tanto sorprendente. Minerva es la valerosa hija de Júpiter, nacida de su cabeza, diosa de la guerra, pero también de la sabiduría y de las ciencias, así como la inventora del arte de hilar, tejer y coser. Su imagen era también bien conocida por los artistas a través de la obra de Cartari y de Alciato, quien le dedica varios de sus emblemas, como prototipo de la virginidad y de la prudencia ${ }^{42}$.

En cuanto a su lectura simbólica, es evidente que el hecho de que ambos aparezcan fuertemente encadenados nos está indicando que lo que se pretende es impedirles que ejerzan los cometidos principales que ambos tenían encomendados: mensajero de Júpiter, en el caso de Mercurio; instigadora de guerras, en el caso de Minerva. Pérez de Moya llama a Minerva "destruidora de ciudades, porque aprovecha su sabiduría y consejo en las cosas de la guerra con que se destruyen fortalezas y ciudades.» ${ }^{43}$. Hay que recordar también que, de las dos diosas perdedoras en el Juicio de París. Minerva fue la que se sintió más despechada, la que manifestó su deseo de vengar su agravio, lo que pudo cumplir pronto al ponerse al lado de los griegos en la contienda de Troya.

Por técnica por modelos, este dibujo hay que relacionarlo con algunos de los testimonios gráficos que de la entrada de Maria Luisa de Orleans se conocen, como el dibujo considerado como un proyecto para la decoración de la Plaza de la Villa o de San Salvador ${ }^{44}$ y, sobre todo, el grabado de uno de los seis tramos que componían la galería de nichos o "Calle de los Reinos", levantada a uno y otro lado del espacio comprendido entre la puerta de los Caballeros

41 En la entrada de Mariana de Austria se representaba en una escultura colocada a la entrada de la plaza de Palacio, formando pareja con otra de Himeneo, dios del matrimonio; en la portada del libro con la descripción de esta entrada, también se representa con ese mismo simbolismo de mensajero de Júpiter, llevando de la mano a Himeneo. En las entradas de María Luisa de Orleans y María Ana de Neoburgo su imagen aparece en diferentes adornos de los arcos y en algunos jeroglíficos.

42 Emblemas XIX, XXII y XXIII.

43 Pérez de Moya, ob. cit., L III, cap. VIII, pág. 248.

44 T. Zapata Fernández de la Hoz, núm. 323 del catalógo de la exposición Propuestas para un Madrid soñado. De Texeira a Castro, Madrid, Centro Cultural Conde Duque, XI-92/I-93, págs. 457-458. 
del Real Sitio del Buen Retiro, y la entrada a la carrera de San Jerónimo, realizados por Claudio Coello ${ }^{45}$. En ambos ejemplos los elementos ornamentales son muy parecidos, con ese aspecto realista escaso relieve, muy menudos, lo que les diferencia de los modelos de Francisco Rizi o Sebastián de Herrera Barnuevo, más carnosos, de relieve mucho más acusado y de mayor tamaño. Están ejecutados con una gran finura y elegancia a base de toques menudos y ligeramente curvos, características de los dibujos de Claudio Coello y sus seguidores ${ }^{46}$.

De las entradas con las que por sus rasgos estilísticos se podría relacionar este dibujo -María Luisa de Orleans (1680), María Ana de Neoburgo (1690) y Felipe V (1701)-, tenemos que descartar las dos primeras por no coincidir con ninguno de los monumentos que en esas ocasiones se fabricaron ${ }^{47}$. Nos queda, por tanto, la de Felipe V, entrada que además se avendría con el simbolismo de pinturas y estatuas, más propia del recibimiento de un monarca que el de una reina. Para la entrada de Felipe V, y por motivos puramente económicos con los que el nuevo monarca se sintió totalmente indentificado, el Ayuntamiento limitó el número de las construcciones efímeras a la galería de arcos levantada a modo de calle artificial entre el Buen Retiro y la carrera de San Jerónimo, de forma similar a las construidas en las dos entradas anteriores; un arco de triunfo a la entrada a la carrera, entre las casas del conde de Aguilar (donde hoy se levanta el Palacio de Villahermosa) y el jardín de las casas de los Duques de Lerma (ocupado en la actualidad por el Hotel Palace), arco que no podía faltar por simbolizar, desde el momento en que el nuevo rey o la nueva reina lo atravesaba, su entrada triunfal en la Corte, su toma de posesión, emulando a los emperadores de la Antigua Roma, ratificada por la entrega de las llaves de la ciudad que los miembros del Ayuntamiento le hacían nada más traspasarlo; un Monte Parnaso, situado en la carrera de San Jerónimo, enfrente del convento del Espíritu Santo (lugar que hoy ocupa el Congreso de los Diputados), y dos carros triunfales que, como en las entradas anteriores, debían esperar en la plaza de Palacio la llegada del nuevo rey para acompañarlo hasta la puerta del Alcazar, ocupados por actrices, cantantes y músicos de las compañías de teatro de la Corte, encargadas de entonar canciones de alabanza a su persona ${ }^{48}$.

Aunque por las descripciones que sobre esta entrada, efectuada el 14-IV-1701, conocemos ${ }^{49}$, así como por los documentos conservados en el Archivo de la Villa ${ }^{50}$, el dibujo no coincide con ninguna de las dos decoraciones principales, su estructura sí guarda muchas semejanzas con uno de los tramos que formaban la calle artificial. Según los documentos, formaban esta ca-

45 T. Zapata Fdez. DE la Hoz, "Proyecto del Ayuntamiento madrileño para el libro de la Entrada en la Corte de la reina María Luisa de Orleans (1680)", Villa de Madrid, 1991, núms. 105-106, págs. 3-27. El hecho de que en la Exposición del Antiguo Madrid el dibujo figurara como una decoración para la plazuela de la Villa de esta entrada, lo mismo que el grabado de Claudio Coello (núm. 357, como anónimo), me hizo suponer que los dos representaban lo mismo (T. ZAPATA, "Claudio Coello: Dibujos festivos", A.E.A., 1993, pág. 277).

46 A. E. Pérez Historia del dibujo en España. De la Edad Media a Goya, Cátedra, Madrid, 1986.

47 Estas entradas han sido estudiadas en mi Tesis doctoral, Arquitecturas efímeras y festivas en Madrid durante la segunda mitad del siglo xvIr: las Entradas Reales, Madrid, Ediciones de la U.A.M., 1993 (microfichas).

48 Además de estos adornos y como era habitual, las comunidades religiosas de los conventos de la Victoria, al final de la carrera de San Jerónimo, y de San Felipe El Real, a la entrada de la calle Mayor, adornaron sus lonjas; por su parte, los gremios más importantes - mercaderes de seda de la Puerta de Guadalajara, pretineros y peleteros, pellejeros, guarnicioneros y plateros- adornaron los tramos correspondientes de la calle Mayor donde estaban ubicados sus tiendas y talleres. Por último, los Consejos de Indias, Hacienda, Ordenes Militares y Flandes levantaron diferentes arcos en las bocacalles de la calle Mayor desde donde asistieron a la ceremonia de la entrada.

49 Descripcion del adorno, que se hizo en esta Corte a la Real Entrada de su Magestad nuestro Catolico Rey Don Felipe Qvinto, el dia catorze de Abril, desde el Buen Retiro al Palacio, con el aparato del Arco, Monte Parnaso, y distancia del Prado, y Carrera hasta el palacio. de Sus Geroglificos, Motes, y demas Inscripciones, segun sentido literal, Historico o natural al assumpto [Madrid, 1701]; Prosigue la descripcion de la primera parte hasta la ida, y buelta a nuestra Señora de Atocha, con la interpretacion de las dos Carreras de los versos, y poesias, retrocediendo a San Felipe hasta nuestra Señora de Belen, escritos de diversos ingenios, obra de gusto, sin omitir lo serio, [Madrid, 1701].

50 ASA (Archivo Secretaría del Ayuntamiento), 2-65-1 y 2-66-25. 
lle un total de seis tramos, tres a cada lado, separados entre si por corredores de balaustres. Cada tramo estaba compuesto de un total de seis arquillos cerrados por detrás con lienzo, tres a cada lado de otro central de mayor tamaño, abierto para que pudiera pasar la gente ${ }^{51}$. Como podemos observar, el tramo de arquitectura que nos muestra el dibujo es muy parecido, con ese hueco central, suficiente para que pase la gente, pero demasiado estrecho para que lo atraviese una comitiva, a modo de arco de triunfo ${ }^{52}$, y tres tramos a cada lado, de los cuales el tercero está únicamente indicado.

Cada uno de estos tramos se adornaba con ocho estatuas de pie, sobre pedestales, que personificaban los diferentes reinos de la monarquía y los signos del Zodiaco - seis de los reinos y dos del Zodiaco-, que por el número tuvieron que ir colocadas a uno y otro lado de cada arquillo, seguramente apoyadas sobre las pilastras de separación entre cada hueco (en total fueron 48 estatuas, 36 de los reinos y 12 de los signos del Zodiaco) ${ }^{53}$, y seis lienzos que ocupaban todo el espacio de los arcos, en los que se pintaron diferentes jeroglíficos (en total fueron 36 jeroglíficos). La clave de cada arquillo se adornaba con un jarrón de flores y frutos colocado sobre una peana, sostenido por dos niños de cuerpo entero en diferentes actitudes, además de otros adornos. Los corredores que separaban cada tramo se adornaban con estatuas de medio cuerpo que representaban a emperadores romanos, «a lo antiguo». El armazón de esta decoración, realizado en madera, iba pintado imitando mármoles y jaspes de diferentes colores; las cabezas, manos y pies de las estatuas se fabricaron en madera estofada, mientras que los vestidos eran lienzo encolado y encarnado en diferentes colores; los niños, de pasta «bien furtida», iban estañados y corlados; los adornos de relieve, tarjetas y molduras eran también de pasta e iban igualmente estañados.

Aunque esta decoración tampoco coincide con el dibujo, sí quiero señalar que, aparte de los bustos de los emperadores, que en el dibujo coronan los tramos de las hornacinas, entre los jeroglíficos pintados en los lienzos de los arquillos había uno que representaba a Paris con las tres diosas, entregando a Venus una corona, y otro con Faetón conduciendo el carro del Sol, tirado por cuatro caballos, sobre un globo terrestre pintado debajo. El de Paris iba acompañado de esta letra:

\section{De París nuestra ventura \\ Siguio el juizio, y tanto honor, \\ Sin agrauiar al valor, \\ Le concedió a la hermosura.}

La explicación que nos proporciona el texto de la relación es la siguiente: «Las tres Deidades son los tres Hermanos: el juizio de París, u (de Párís) hizo elección, y donación, con su prudente consejo, del mas hermoso, assi en lo personal, como en las demas virtudes, que es la mayor her-

51 En la citada Descripcion del adorno..., cada uno de estos tramos está considerado como dos, por lo que se hace referencia a un total de seis tramos, de tres arquillos cada uno, en cada lado de la calle, en lugar de tres tramos de seis arquillos cada uno, como se indica en los documentos.

52 Por las descripciones y documentos de esta entrada, este arco constaba de tres huecos o pasos, uno central de mayor tamaño y dos laterales. Separado por una cornisa, se levantaba un segundo piso, cuyo adorno principal era un lienzo que representaba la Toma de Sevilla por el Rey San Fernando, en la fachada principal, y la Conquista de Jerusalen por San Luis Rey de Francia, en la fachada posterior, además de diferentes estatuas y jeroglíficos. Coronaba esta arquitectura las Armas Reales sobre un pedestal, flanqueadas por dos estatuas que personificaban al Amor y a la Esperanza, en la fachada principal, y las Armas antiguas de Madrid con las estatuas del Mérito y la Felicidad pública, en la fachada posterior.

53 A.S.A., 2-65-1. Sobre esta entrada véanse los arts. de E. Villena y C. SÁenz de Miera, "La entrada real de Felipe V en Madrid en 1701", Villa de Madrid, 1987-I, núm. 91, págs. 63-77, y T. ZAPATA Fdez. DE LA Hoz, "Proyecto y participación de Teodoro Ardemans en la entrada pública en Madrid de Felipe V», A.E.A., 1991, núm. 255, págs. 361-372. 
mosura, a quien no obsta lo bizarro, y valeroso, como lo muestra su robustez (que ay hermosuras fieras)" ${ }^{54}$. Es evidente que la elección de Paris se interpreta aquí como algo positivo. No es desencadenante de ninguna guerra; no supone el rechazo del poder y la sabiduría ante la tentación del amor carnal, sino que se trata de una elección afortunada: el triunfo de la Belleza, como cualidad moral y física, el mismo significado simbólico que le había dado Palomino en la decoración del calesín. Felipe $\mathrm{V}$ encarna esa Belleza, vencedora frente a las otras dos diosas, símbolos del Poder y la Riqueza, personificadas en los otros dos candidatos al trono español -Fernando José de Baviera y el Archiduque Carlos de Austria-, que con Felipe de Anjou serían los «tres hermanos» a los que se refiere el texto.

La letra que acompañaba al jeroglífico de Faetón era la siguiente:

\section{Domeñar brutos fogosos \\ Desde el primer arrebol, Es el oficio del Sol.}

Como en el caso anterior, la interpretación de la acción de Faetón es totalmente positiva. Dice el texto: «Tambien se deriva del Sol Soldado; estos son los que con mas propiedad sujetan los cavallos, y aún los mas ferozes, como son los de nuestra Esfera Vetica. Bien lo muestra nuestro Faetonte, farigando todos los días su ligereza, y velocidad, con cuyas huellas se avassallan Mundos.» ${ }^{55}$. Faetón se identifica con el Sol y se toma como ejemplo de soldado fuerte y valeroso, personificado en Felipe V, capaz de gobernar con firmeza a sus nuevos súbditos y vencer a sus enemigos. En ambos casos, el significado simbólico se aparta bastante de las interpretaciones de contenido más o menos moralizante dadas por los diversos autores, lo que pone de manifiesto, una vez más, la pluralidad de significados, de lecturas que podían tener los jeroglíficos o las historias de los cuadros. Una misma imagen podía significar cosas distintas, incluso contrarias, según la utilización que en cada ocasión quisiera darle la persona encargada de su invención ${ }^{56}$. El mote o los versos escritos en las cartelas que siempre acompañaban a estos cuadros y jeroglíficos, así como a las estatuas, tenían por misión el aclarar su significado a cuantos los contemplaban. Idéntica misión cumplían los folletos que se publicaban antes de la ceremonia con la descripción de los adornos y, sobre todo, con la explicación del significado de cuadros, estatuas y jeroglíficos, a modo de guía, como la relación de la entrada de Felipe V.

Aunque las escenas representadas en las cartelas del dibujo no son exactamente las mismas, sí son los suficientemente parecidas como para poder interpretarlas de una forma más acorde con el pensamiento del momento. El Juicio de Paris podría significar los mismo: Paris, símbolo del hombre juicioso, podría personificar el gobierno de la monarquía, al pueblo español que había elegido como sucesor de Carlos II al joven y apuesto Felipe de Anjou, modelo de virtudes, símbolo de la Belleza. Esta elección se había efectuado con el beneplácito de los poderes divinos, simbolizados en Mercurio, hijo y mensajero de Júpiter, quien siguiendo instrucciones de su padre lo había acompañado a su nuevo reino, desempeñando, de esta forma, el mismo papel que el dios Himeneo en las entradas de las reinas.

\footnotetext{
54 Descripción del adorno..., pág. 20.

55 Ibid., pág. 22.

56 Es evidente que los artistas debían de recibir instrucciones muy precisas sobre los símbolos que tenían que pintar en los jeroglíficos, así como las historias que tenían que representar en los cuadros. Aunque en relación con las entradas no he localizado ninguna de estas instrucciones, en la entrada de María Ana de Neoburgo (1690) sí se indica en uno de los documento que los autores de las letras de los jeroglíficos debían de entregárselas a los pintores para que estos fueran pintando las imágenes. De las exequias de Felipe IV en Madrid se conserva el documento con las letras de los jeroglíficos y la indicación de lo que se tenía que pintar en el cuerpo de los mismos.
} 
La escena de Faetón pidiendo el carro a su padre el Sol simbolizaría la petición de Felipe V a Carlos II, identificado con el Sol, de ser reconocido como hijo suyo, como su legítimo heredero, de la misma manera que Faetón se lo pidió a su padre; la confirmación de su elección; el permiso para conducir la máquina del estado, privilegio del Rey Sol. La escena de Faetón conduciendo el carro, de la parte superior, simboliza ese reconocimiento, la ratificación de su elección como su sucesor, la legitimación de la nueva dinastía borbónica. Sobre la identificación de Carlos II con el dios Sol, es muy interesante el grabado del pintor lucense Leonardo Antonio de Castro, en el que el monarca aparece sentado en el trono en el interior de un palacio, que se abre a la derecha para dejar ver al fondo un gran Sol rodeado de rayos, de forma muy parecida a la representación del dios Sol en su palacio de las Metamorfosis ${ }^{57}$ (Fig. 9).

En cuanto a las estatuas, la de Mercurio encadenado significaría que, una vez cumplida su misión de acompañar a Felipe $\mathrm{V}$-simbolizado en la Belleza- ante la presencia de Paris por expreso deseo de Júpiter, no se desea que exista la posibilidad de que regrese con otro candidato. La de Minerva encadenada significaría el deseo de la monarquía española, de sus súbditos, de que esta elección, auspiciada por los más altos poderes celestiales, meditada por los poderes terrenales y ratificada por Carlos II, fuera respetada por todos, para de esta forma evitar los enfrentamientos, presentes en el ánimo de todos 58 .

Por último, los bustos de los emperadores romanos que coronan los dos tramos de las hornacinas son elementos decorativos y simbólicos, utilizados en las dos entradas anteriores para adornar las dos amplias galerías de arcadas que limitaban el patio principal del Palacio por sus lados este y oeste ${ }^{59}$. En la entrada de María Luisa estos bustos se alternaron con estatuas que personificaban los Ríos más famosos de España, a un lado, y las Fuentes, al otro. Unos y otros coronaban las balaustradas que remataba las arquerías. Aunque las estatuas de los fuentes y los ríos se fabricaron en yeso imitando el alabastro, los bustos eran de mármol y debían proceder del Palacio o de algún Real Sitio. Seguramente eran los mismos bustos que en época de Felipe IV estaban en el Jardín de los Emperadores del Alcazar madrileño, situado al pie de la Torre dorada, llamado así precisamente por las estatuas de emperadores romanos que lo adornaban 60 . De estas estatuas, unas eran bustos, copias de originales romanos regaladas en 1561 por el Cardenal Giovanni Ricci di Montepulciano; otras habían sido regaladas por el Papa Pío V. En la entrada de María Ana de Neoburgo se volvieron a colocar los bustos de mármol de los emperadores en las barandillas de las galerías de la plaza, bustos que se quitaron pasadas las fiestas. Con motivo de la proclamación de Felipe V, el 24 de noviembre de 1700, la plaza de Palacio se volvió a decorar con los bustos de los emperadores, como se aprecia en el dibujo de Filippo Pallotta del Museo Municipal de Madrid, realizado para testimoniar el acontecimiento ${ }^{61}$. Finalmente, y como he indicado, se utilizaron bustos de emperadores romanos para adornar las balaustradas

57 Publicado por J. M. Morales Folguera en "La Influencia de la mitografía y de la literatura", Cuadernos de Arte e Iconografía, F.U.E., 1991, T. IV, núm. 8, lám. XXIV. La identificación del Rey de España con el dios Sol es bastante frecuente durante el siglo XvII y muy especialmente durante el reinado de Carlos II, donde se utiliza en grabados alegóricos, en jeroglíficos, así como en las decoraciones de las entradas de sus dos esposas.

$58 \mathrm{El} 1 .^{\circ}$ de febrero de 1701, Luis XIV, abuelo de Felipe V, en contra de lo establecido por Carlos II en su testamento, comunicó que sus descendientes conservarían todos sus derechos a la corona de Francia, lo que equivalía a una declaración de guerra. El 15 de mayo de 1702, Austria y las potencias marítimas declararon la guerra a Francia, dando principio a la Guerra de Sucesión española.

59 La construcción, en 1675, de las dos galerías de arcadas que limitaban la plaza por el este y el oeste, según traza de José del Olmo, así como el gran arco contiguo a la Armería Real, en 1676, que cerraba la plaza por el sur, obra también de ese arquitecto, transformaron su estructura en un espacio cerrado, convirtiéndose desde ese momento en un lugar privilegiado para la celebración de fiestas.

60 J. E. Varey y N. D. Shergold en su edición de Los celos hacen estrellas, de J. Vélez Guevara, Tamesis Books Limited, London, 1970, págs. lviii y lix.

61 Museo Municipal, Madrid. Testimonios de su historia hasta 1875, Madrid, 198O, núm. 609. 

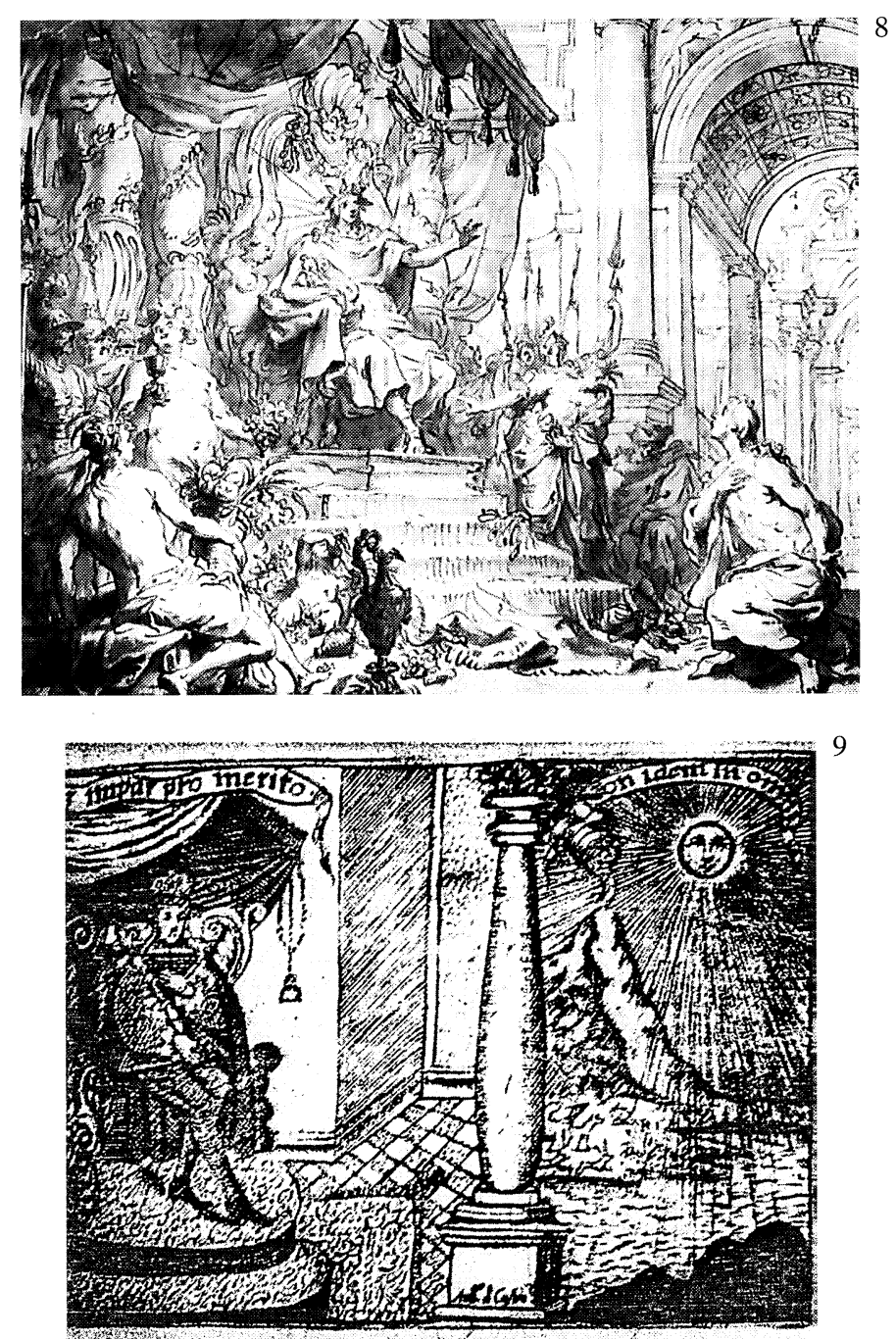

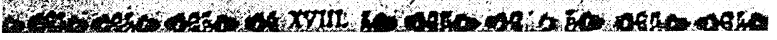

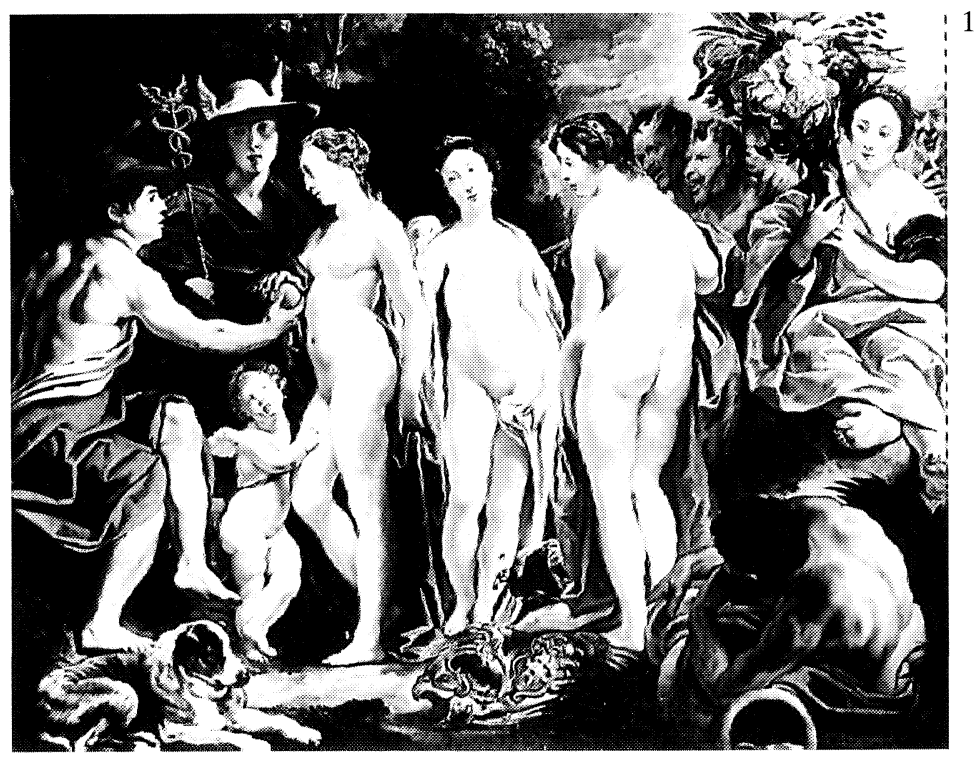

Fig. 8. Faetón pide al dios Sol que le deje conducir su carro, grabado de B. Picart.

Fig. 9. Carlos II como dios Sol, grabado de L. Antonio de Castro.

Fig. 10. El Juicio de París, J. Jordaens. Washington, National Gallery. 
que unían los tramos que formaban la calle de los reinos de la entrada de Felipe V, aunque en esta ocasión no eran de mármol, sino de pasta de papel imitando el jaspe blanco ${ }^{62}$. Su presencia en las entradas reales pone de manifiesto, una vez más, la íntima relación que se quería establecer entre los hechos, las hazañas, los triunfos, el poder de la Antigua Roma y la monarquía española.

Creo que podemos considerar este dibujo, al menos de forma provisional, como un primer proyecto para uno de los tramos que debían formar la calle artificial que, como era ya tradición, se levantaba en las entradas reales para unir el Real Sitio del Buen Retiro, a las afueras de la villa, con el Prado de San Jerónimo, y que servía además para ocultar el mal estado en que se encontraba el Prado de Atocha. Por motivos que desconocemos, se debió de preferir el diseño más tradicional, empleado en otras entradas, como la de María Luisa de Orleans, consistente en una sucesión de arcos o nichos, que sirvieran de marco, fundamentalmente, a las representaciones escultóricas de los Reinos de la monarquía.

La dirección y supervisión artística de las decoraciones para la entrada de Felipe V estuvo a cargo de Teodoro Ardemans, Teniente de Maestro Mayor, «quien tiene las ausencias y enfermedades del Maestro Mayor de Madrid" 63, puesto que ocupaba José del Olmo. Ardemans, al igual que habla hecho José del Olmo en las entradas de María Luisa de Orleans y María Ana de Neoburgo ${ }^{64}$, se encargó de redactar las condiciones para fabricar los adornos, de dibujar las trazas, de supervisar su realización, tasar las demasías, redactar informes sobre el estado de ejecución de las obras; es decir, todas aquellas obligaciones que el cargo de Maestro mayor de la Villa conllevaba. La construcción de todos los monumentos de esta entrada -calle de los reinos, arco del Prado, Monte Parnaso y los dos carros triunfales- estuvo a cargo de José de Churriguera, Francisco Alvarez. Manuel Arredondo, Juan de Ribera y Pedro de Araujo, «profesores del arte de la Arquitectura", todos residentes en la Corte, según la traza y condiciones de Teodoro Ardemans 65 .

De Ardemans se conserva un dibujo firmado para el Monte Parnaso de esta entrada ${ }^{66}$, que, aun teniendo en cuenta de que se trata de un dibujo mucho menos elaborado, es muy diferente, en cuanto a técnica y modelos, al que nos ocupa. Igualmente, resulta difícil relacionarlo con otros dibujos suyos tan elaborados como éste, como los que se conservan en la Biblioteca Nacional de Madrid ${ }^{67}$, realizados también para que fueran aprobados por el comitente, por lo que su ejecución es muy cuidada y detallada, con el empleo de tintas y aguadas de colores, generalmente sepias y azuladas, de forma que se aproximaran lo máximo posible a la obra definitiva. Si bien algunos de los elementos ornamentales son análogos, las figuras son muy diferentes, lo mismo que la técnica. En Ardemans el trazo es más blando, más suave, las figuras son más voluminosas, mientras que este dibujo está realizado con un trazo muy fino, aunque discontinuo, marcando mucho los contornos de las figuras.

62 A.S.A., 2-65-1.

63 Ibid.

64 Aunque M..$^{\circ}$ A. Toajas, en "La ciudad transfigurada. Ideas y proyectos para obras efímeras en Madrid (s. XVII-XIX)" dice, entre otras cosas, que Teodoro Ardemans dirigió los diseños para la entrada de María Ana de Neoburgo (pág. 121, nota 53 del catálogo de la exposición Propuestas para un Madrid soñado), fue José del Olmo, como Maestro mayor de la Villa, el que desempeñó ese papel principal. Ardemans se limitó a pintar los jeroglíficos de la galería de nichos levantada entre el Buen Retiro y la entrada a la carrera de San Jerónimo.

65 A.S.A., 2-65-1. Arts. cits. de E. Villena y C. SAenz de Miera, pág. 68 y de T. Zapata Fdez. de la Hoz, pág. 365.

${ }_{66}$ T. ZAPATA FDEZ. DE LA Hoz, art. cit., fig. 9; catálogo de la exposición Dibujos de arquitectura y ornamentación de la Biblioteca Nacional, Madrid, 1991, núm. 63.

67 Proyecto para una capilla de Santa Teresa, firmado, y el retablo para la iglesia del convento de Santa Teresa, de Madrid, atribuido (núms. 61 y 60 del citado catálogo de la exposición Dibujos de arquitectura y ornamentación...). Sobre este pintor y arquitecto véase la Tesis doctoral de B. Blasco Esquivias, Teodoro Ardemans y su entorno en el cambio de siglo (1661-1726), U.C.M., 1991 (inédita). 
El hecho de que en la Exposición del Antiguo Madrid este dibujo figurara como «dibujo original de José Churriguera», unido a la circunstancia de que este arquitecto, junto con sus compañeros, se encargara de fabricar las decoraciones de esta entrada, puede llevarnos a pensar en él como su posible autor. De este artista se conservan una serie de dibujos para diferentes retablos, considerados de su primera etapa, la mayoría también muy terminados por tratarse, igualmente, de proyectos para ser presentados al comitente, como los de la Merced y San Basilio, de la Academia de Bellas Artes de San Fernando de Madrid; los de la Trinidad y las Calatravas, de la Biblioteca Nacional y del Archivo Histórico Nacional de Madrid ${ }^{68}$, y el proyecto para el retablo de la iglesia del Nuevo Baztán, del Museo del Prado ${ }^{69}$. En todos ellos, muchos de los elementos ornamentales guardan bastantes semejanzas con los de este dibujo -colgantes de racimos de flores y frutos, guirnaldas, volutas tipo orejeras, jarrones con incrustaciones, ranuras, fustes ceñidos con cintas o guirnaldas, etcétera-, teniendo siempre en cuenta que todos han sido realizados en fechas posteriores y para un destino diferente. En cuanto a la técnica, Churriguera, como otros artistas de finales del siglo XVII y principios del XVIII formados en la escuela madrileña, utiliza una técnica parecida a la de Claudio Coello ${ }^{70}$, sobre todo en su primera etapa, técnica que pone al servicio de unas dotes excepcionales de dibujante, como lo evidencien los ejemplos antes citados. La calidad del dibujo que nos ocupa, la finura, la gracia, el preciosismo, la exhuberancia, el caudal imaginativo de su lenguaje ornamental, creo que están más acordes con las características de José de Churriguera, considerado como el máximo diseñador de arquitectura y decoración de su tiempo, que con las de Ardemans, por lo que podría tratarse perfectamente de un proyecto de ese artista para la entrada en Madrid de Felipe V, rechazado por la Junta, seguramente por preferir un diseño dentro de la línea de los realizados en entradas anteriores, como fue el que se construyó finalmente, diseñado por Teodoro Ardemans, quien, además, desempeñaba en ese momento el cargo de arquitecto oficial de la Villa ${ }^{71}$.

De todas formas, y teniendo en cuenta las dificultades que la catalogación de dibujos entraña, debido, fundamentalmente, a su escasez, a la ausencia de firmas, a la íntima colaboración entre los artistas de ese momento, no se puede descartar, si no la autoría, al menos la participación de los otros artistas que trabajaron con Churriguera en esta entrada, de los que, hasta la fecha, no se conoce ninguna traza o dibujo de su mano y que, sin embargo, en estos momentos están trabajando para la Villa y para la Casa Real en obras efímeras, como catafalcos. A este respecto, es interesante señalar que algunos de los elementos decorativos del dibujo, como el arco central con el almohadillado decorado alternando rosetas con ranuras pareadas, las volutas aveneradas del

68 A. Rodriguez G. de Ceballos, Los Churriguera, Madrid, 1971, láms. 13 y 34; A. Bonet Correa, «Los retablos de la iglesia de las Calatravas de Madrid", A.E.A., 1962, lám. II; A. E. Pérez Sánchez, El dibudo español de los Siglos de Oro, Madrid, 1980, láms. CVIII y CIX.

69 A. E. Pérez Sánchez, "Dos dibujos churriguerescos", Boletín del Museo del Prado, T. X, 1989, págs. 49-53.

70 A. E. Pérez SÁnchez, Historia del Dibujo en España, ob. cit., págs. 330-331. Las relaciones de Churriguera con los pintores-decoradores de la escuela madrileña se efectuaron a través de su abuelo adoptivo, José Ratés, en cuyo taller se formó, y de José Donoso, relacionado personalmente con Ratés y con la familia de los Churriguera (A. GARCía Y BELLIDO, "Estudios del barroco español. Avance para una monografía de los Churriguera», A.E.A.A., 1929, págs. 21-86; MARQUÉS DE SAltillo, "Los Churrigueras. Datos y noticias inéditas (1679-1727)", Arte Español, 1945, págs. 83-106.

71 La actividad de José de Churriguera en obras de carácter efímero había comenzado en 1689 cuando ganó el concurso del catafalco para las exequias de María Luisa de Orleans, en la iglesia de la Encarnación de Madrid, del que se conoce el grabado, realizado por Francisco Ignacio Ruiz de la Iglesia (Rodriguez G. DE CEBAllos, ob. cit., lám. 6). Comparado con él, el dibujo de la Biblioteca Nacional supondría un avance considerable hacia un barroco más movido en la arquitectura y más exhuberante en lo decorativo, dentro de la línea de los arquitectos-pintores de la escuela madrileña de finales del siglo XviI, acorde, por otro lado, con la progresiva evolución que se advierte en la obra de este artista. En 1690, realiza la traza y construye el catafalco para las exequias del Elector Palatino, padre de María Ana de Neoburgo, en la capilla del Palacio Real, cuando ya tenía el cargo de Ayuda de trazador de las Obras reales, bajo las órdenes de José del Olmo (A.G.P., Sec. hist., C 80 ), del que no se conoce la traza. 
del coronamiento, la insistencia en las incrustaciones, no sólo en la arquitectura, sino en jarrones y flameros, recuerdan a Pedro de Ribera, y aunque hay que descartar su participación en esta entrada ${ }^{72}$, si es segura, como he indicado más arriba, la de su padre, Juan de Ribera, con quien lógicamente debió de formarse y del que se conocen muy pocos datos ${ }^{73}$.

En cualquier caso, independientemente de quien sea su autor, es evidente que estamos ante uno de los dibujos más sugestivos del barroco efimero, en el que se resume, por una parte, todo el lenguaje ornamental y figurativo de finales del siglo XVII y principios del xVIII, que partiendo de Francisco Rizi y Sebastián de Herrera Barnuevo pasará, más italianizado, a Francisco de Herrera, a José Donoso y a Claudio Coello, quienes lo transmitirán a sus discípulos y colaboradores, prolongando de esta forma la tradición madrileña durante los primeros años del siglo XVIII ${ }^{74}$. Por otra parte, se trata de un ejemplo interesantísimo de la compleja iconografia que se desarrollaba en estas arquitecturas o decoraciones efimeras, expresión última del poder de la monarquía, de la «majestad real».

De una gran calidad, muy cuidado en la ejecución y bellísimo en las formas, hay que atribuirlo a un pintor-arquitecto o a un arquitecto-decorador próximo al estilo de Claudio Coello, probablemente a José de Churriguera, realizado para ser presentado como proyecto para una de las decoraciones que se debían de levantar para la entrada de Felipe V en la Corte, pero que, finalmente, no fue aceptado.

Por todo ello, debemos de congratularnos de su recuperación, después de haber permanecido durante varios años en paradero desconocido, y aún más de que venga a aumentar los magníficos fondos de dibujo de la Sección de Dibujos y Grabados de la Biblioteca Nacional de Madrid, añadiéndose a los que ya conserva de las entradas de Mariana de Austria, María Luisa de Orleans y Felipe V 75 .

72 Nacido en 1681, la primera noticia que se tiene de su actividad artística es de 1711, cuando participa con su padre, Juan de Ribera, con Manuel de Arredondo y con Francisco Alvárez en el túmulo para las exequias de la Casa Real por el Delfín de Francia (Bottineau, El arte cortesano en la España de Felipe V; Madrid, 1986; T. ZAPATA, art. cit., pág. 368). Este extremo me ha sido confirmado por MATILDE Verdú, autora de la Tesis doctoral, El arquitecto Pedro de Ribera (1681-1742), U.C.M., 1993 (inédita).

73 Además de su participación en la construcción del túmulo del Delfín (véase nota anterior), trabajó bajo las órdenes de Carlier en las reformas de la pieza de las Furias y en el Salón Nuevo o de los Grandes, del Palacio Real de Madrid (BotTineau, ob. cit., págs. 449 y 487 ).

74 Las relaciones entre estos pintores-decoradores o arquitectos-pintores y los ensambladores, escultores y entalladores fueron muy estrechas, tanto en el campo de lo efímero como en el de los retablos. Francisco Rizi trabajó con Pedro de la Torre y con Sebastián de Herrera Barnuevo en la entrada de Mariana de Austria (1649); José Donoso y Claudio Coello trabajaron con José Ratés, José de Acedo, Sebastián de Benavente, Juan Pérez Ignacio de Fox, Francisco y José de la Torre, Pedro Alonso de los Ríos y otros en la entrada de María Luisa de Orleans (1680); en la entrada de María Ana de Neoburgo (1690) encontramos a los discípulos de Donoso y Claudio Coello, como Ruiz de la Iglesia, Palomino y Ardemans, trabajando con Manuel de Arredondo, Juan de Campo Redondo, Francisco de Mesa, Roque de Tapia y otros, colaboraciones que se dieron igualmente en la construcción de retablos para las iglesias de Madrid y su provincia. Por ejemplo, Claudio Coello fue el responsable último del retablo de San Esteban de Salamanca, cuya ejecución se contrató con José de Churriguera en 1692 (Rodriguez G. DE Ceballos, ob. cit., pág. 20).

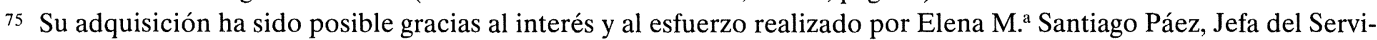
cio de Dibujos y Grabados de la Biblioteca Nacional de Madrid. 